Open Access

\title{
Analgesic and Anti-Gastropathic Effects of Salidroside Isolated from Acer tegmentosum Heartwood
}

\author{
Yeong-Min Yoo a,e Jung-Hwan Nam ${ }^{\mathrm{b}}$, Min-Young Kim ${ }^{\mathrm{a}}$, Jongwon Choi ${ }^{\mathrm{c}}$, Kyung-Tae Lee ${ }^{\mathrm{d}}$ and \\ Hee-Juhn Park ${ }^{\mathrm{a}, *}$
}

${ }^{a}$ Department of $P$ harmaceutical E ngineering, Sangji Univ ersity, Woosan-dong, W onju 660, Gangw on-do 220-702, Korea, ${ }^{b}$ Highland A griculture Ins titute, R ural De velopment A dministration, Pyongchang 232-950, Korea, ${ }^{c}$ College of Pharmacy, Kyungsung University, Busan 608-736, Korea, ${ }^{d}$ College of Pharmacy, Kyung-Hee University, Dongdaemunku, Seoul 130-701, Korea, ${ }^{e}$ Department of Veterinary Medicine, Chungbuk National University, Cheongju, Chungbuk 361-763, Korea

\begin{abstract}
The heartwood of Acer tegmentosum (Acereaceae) has been used as a Korean traditional medicinal drug against alcohol poisoning and hepatitis. To find the biologically active substance in A. tegmentosum heartwood, we investigated the protective effects of the heartwood extract and its constituents on pain and gastropathy in mouse. In these experiments, salidroside, a major compound, significantly reduced gastric lesion and pain in mice. Oral administration of salidroside at the 10 and $20 \mathrm{mg} / \mathrm{kg}$ doses greatly reduced the gastric lesion induced by $\mathrm{HCl} / \mathrm{ethanol} \mathrm{(inhibitory} \mathrm{effect,} 51.5$ and $68.8 \%$, respectively) and by indomethacin/bethanechol (inhibitory effect, 31.3 and $38.8 \%$, respectively). Salidroside also stabilized $\mathrm{pH}$ of gastric juice and the increase of gastric juice secretion and total acid output. Taken together, these results demonstrated that salidroside is the main ingredient of A. tegmentosum heartwood to prevent gastric lesion and pain that can be caused by drinking alcohol.
\end{abstract}

Keywords: Acer tegmentosum, salidroside, analgesic, gastropathic.

\section{INTRODUCTION}

Gastroesophageal reflux disease and peptic ulcer are the most important and common gastrointestinal disorders [1]. Peptic ulcers have a prevalence of $4-5 \%$ in humans and are related to food, stress, genetic and environmental factors [2]. Major causative factors of peptic ulcer involve Helicobacter pylori infection, excessive abuse of drugs such as nonsteroidal anti-inflammatory drugs (NSAIDs), irregular eating habits, smoking, alcohol consumption, and psychological stresses [3]. Peptic ulcers occur in tissues destroyed by gastric juice and stomach acid because of an imbalance between aggressive factors (e.g., stomach acid and pepsin) and defensive factors (e.g., mucus, bicarbonate and mucosa blood flow) in the digestive system; this imbalance results in impairment of the mucosa and muscularis mucosa. In addition, reactive oxygen species (ROS) and lipid peroxidation by oxidative stress can lead to gastric mucosal lesions [4]. Once ROS trigger and maintain ischemic status in the gastric mucosa, hydroxyl radicals generated from superoxide anions cause gastric lesions by virtue of damage to the mucosa microvessels and the subsequent decrease in blood flow [5].

The leaves and heartwood of Acer tegmentosum (Acereaceae) have been used in Korean traditional medicine for alcohol and liver detoxification. Its heartwood has been used to treat liver diseases including liver cirrhosis and liver cancer. Internal use of heartwood extract prior to drinking has

*Address correspondence to this author at the Department of Pharmaceutical Engineering, Sangji University, Wonju 660, Gangwon-do 220-702, Korea; Tel: +82-33-730-0564; Fax: +82-33-730-0564;

E-mail: hjpark@sangji.ac.kr also been known to prevent alcohol poisoning $[6,7]$. In previous studies, diarylheptanoids [8], rhododendrol glycoside [9], tannins [10] and phenolic glycosides (catechin, fraxin, and derivatives of quercetin, flavones and morin) [11] were isolated from the genus Acer. However, the phytochemical constituent with biological activity in A. tegmentosum has not been reported. In the course of our studies of biologically active compounds from Korean natural resources, we investigated the protective effect of the extract and constituent of A. teg mentosum heartwoods on mouse models of pain and gastric lesion.

\section{MATERIALS AND METHODS}

\section{Instruments and Materials}

Melting point was determined on an Electrothermal 9100 melting point apparatus and was uncorrected. The ${ }^{1} \mathrm{H}-\mathrm{NMR}$ spectra $(\delta \mathrm{ppm}, J$ in $\mathrm{Hz})$ was recorded in DMSO- $d_{6}$ on a Brucker AM-500 spectrometer (500 MHz), while ${ }^{13} \mathrm{C}-\mathrm{NMR}$ spectra was recorded in the same solvent on a Brucker AM500 spectrometer at $125 \mathrm{MHz}$ with tetramethylsilane (TMS) as an internal standard.

\section{Extraction, Fractionation and Isolation}

The heartwood of A. tegimentosum was collected in Pyongchang-gun, Gangwon province in Korea and dried. This plant was identified by Dr. Won-Bae Kim of Highland Agriculture Institute, Rural Development Administration of Korea. Heartwoods of A. tegmentosum $(2 \mathrm{~kg})$ were extracted with $\mathrm{MeOH}$ (each, $3.0 \mathrm{~L}$ ) for $5 \mathrm{~h}$ three times under reflux. The extracted solution was filtered and concentrated under reduced pressure to give a viscous $\mathrm{MeOH}$ extract, which was 
freeze-dried to yield a powdery $\mathrm{MeOH}$ extract. A portion $(118.7 \mathrm{~g})$ of the $\mathrm{MeOH}$ extract was suspended in $800 \mathrm{ml}$ distilled water and partitioned three times with $\mathrm{CHCl}_{3}$ (each, $800 \mathrm{ml}$ ). The $\mathrm{CHCl}_{3}$-soluble portion was dried in va cuo to yield the $\mathrm{CHCl}_{3}$ fraction. The $\mathrm{H}_{2} \mathrm{O}$ layer was successively fractionated with $\mathrm{BuOH}$ (each, $800 \mathrm{ml}$ ), and the $\mathrm{BuOH}$ soluble portion was dried in vacuo to yield a $\mathrm{BuOH}$ fraction. Since $\mathrm{BuOH}$ fraction exhibited the most potent antinociceptive andti-gastropathic activity, it was chromatographed for isolation.

Ten grams of the $\mathrm{BuOH}$ fraction was subjected to silica gel column $\left(\mathrm{SiO}_{2}\right.$, Art No. 7734, Merck, Germany, 280 g, 5 $\times 55 \mathrm{~cm}$ ) chromatography and gradiently eluted with $\mathrm{CHCl}_{3}$ $\mathrm{MeOH}$ from $1 \mathrm{~L}$ of $9: 1(\mathrm{v} / \mathrm{v})$ to $2.5 \mathrm{~L}$ of $6: 4(\mathrm{v} / \mathrm{v})\}$. The eluate was collected to give seven fractions (I - VII) and then monitored by checking TLC. Fraction II was dried in vacuo and crystallized from $\mathrm{MeOH}$ to yield a white amorphous powder (2.5 g, compound 1, Fig. 1). Fractions VI and VII were crystallized from $\mathrm{MeOH}$ to yield a white amorphous powder that was identified as sucrose by TLC, ${ }^{1} \mathrm{H}-\mathrm{NMR}$ and ${ }^{13}$ C-NMR.

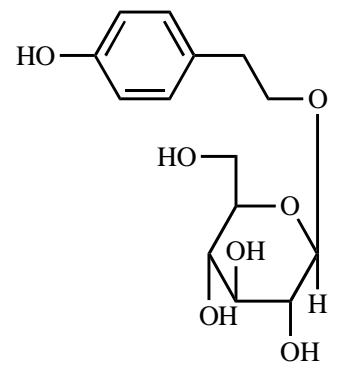

Fig. (1). Chemical structure of salidroside.

Compound 1 - Colorless powder, mp $220^{\circ} \mathrm{C}$; ${ }^{1} \mathrm{H}-$ NMR(500 MHz, DMSO- $\left.d_{6}\right) \delta: 4.17$ (1H, d, J=7.5 Hz, H-1'), $6.67(2 \mathrm{H}, \mathrm{d}, J=8.5 \mathrm{~Hz}, \mathrm{H}-2.6), 7.04(2 \mathrm{H}, \mathrm{d}, J=3,5 \mathrm{~Hz}) ;{ }^{13} \mathrm{C}-$ NMR (125.5 MHz, DMSO- $\left.d_{6}\right) \delta$ : 35.3 (C-7), 61.5(C-6'), 70.3 (C-8), 70.5(C-4'), 73.8 (C-2'), 77.1 (C-3'), 77.3 (C-5', $103.3\left(\mathrm{C}-1^{\prime}\right), 115.4$ (C-2,5), 129.2 (C-1), 130.2 (C-3,5), 155.9 (C-4); FAB-MS m/z $323.2[\mathrm{M}+\mathrm{Na}]^{+}$.

\section{Experimental Animals}

Male ICR mice were purchased from Daehan Bio Link Co. and allowed to adapt to laboratory conditions (temperature: $20 \pm 2{ }^{\circ} \mathrm{C}$, relative humidity: $40-60 \%$, light/dark cycle: $12 \mathrm{~h}$ ) for two weeks. Mice weighing $25 \pm 2 \mathrm{~g}$ were used for experiments. Number of mice was 9 per group. For twentyfour hours before the experiment, the animals were offered only water. Considering that enzyme activities can vary throughout each day, the animals were sacrificed at a fixed time (10:00 A.M.-12:00 P.M.). All experiments were approved by the University of Kyungsung Animal Care and Use Committee. All procedures were conducted in accordance with the "Guide for Care and Use of Laboratory Animals" published by the National Institutes of Health.

\section{Analgesic Experiments}

Acetic Acid-Induced Writhing Method: The $\mathrm{MeOH}$ extract of A. tegmentosum heartwood, its fractions (100 or 200 $\mathrm{mg} / \mathrm{kg}$ ) or compound 1 (10 or $20 \mathrm{mg} / \mathrm{kg}$ ) were orally administered to the mice daily for one week, and the mice were then injected intraperitoneally (i.p.) with $10 \mathrm{mg} / \mathrm{kg}$ of $0.8 \%$ acetic acid ( 9 mice/experimental group) [12]. The number of abdominal contractions in a 20 -min period was then counted. Aspirin (100 mg/kg, p.o.) was used as a positive control. A significant reduction in the number of abdominal contractions compared to the control was considered a positive analgesic response.

Hot Plate Method: Mice (9 mice/experimental group) were administered the $\mathrm{MeOH}$ extract, its fractions (100 or $200 \mathrm{mg} / \mathrm{kg}$ daily), or compound 1 (10 or $20 \mathrm{mg} / \mathrm{kg}$ daily) for 1 week. One $\mathrm{h}$ after the final administration, the mice were placed on a hot-plate (Ugo Basile, Comerio, Italy) maintained at $70^{\circ} \mathrm{C}$. The time until each animal licked a fore or hind paw or jumped off the plate was defined as the reaction time [12]. Morphine (10 mg/kg, p.o.) was used as a reference drug.

\section{Induced Gastric Lesion Experiments}

$\mathrm{HCl} /$ Ethanol-Induced Gastric Lesions in Mice: After oral administration of the test solution, the mice were fasted for 24 hours prior to the experiment. The mice were then given an oral dose of $0.2 \mathrm{~mL}$ of $0.3 \mathrm{M} \mathrm{HCl}$ in $60 \%$ ethanol. After 24 hours the mice were sacrificed, and their stomachs were opened along the greater curvature and fixed in $2 \%$ formalin solution for 10 minutes. After the greater curvature was incised, the extent of gastric damage in the glandular region was defined as the ulcerative lesion index [13].

NSAID-Induced Gastric Lesions in Mice: Test solutions including the $\mathrm{MeOH}$ extract, its fractions (100 and 200 $\mathrm{mg} / \mathrm{kg}$ per day), compound 1 (10 and $20 \mathrm{mg} / \mathrm{kg}$ per day) and the cimetidine control (100 $\mathrm{mg} / \mathrm{kg}$ per day) were orally administered to the mice for 2 weeks. The animals were treated with indomethacin $(30 \mathrm{mg} / \mathrm{kg}$, s.c. $)$ and bethanechol (5 $\mathrm{mg} / \mathrm{kg}$, i.p.), fasted for 1 hour, and then sacrificed. The stomachs were opened along the greater curvature and fixed in $2 \%$ formalin solution for 10 minutes. After the greater curvature was incised, the extent of gastric damage in the glandular region was evaluated according to the ulcerative lesion index [14].

\section{Measurement of Gastric Secretion in Pylorus-Ligated Mice}

Test solutions were administered as previously described and the mice were fasted for 24 hours. Each mouse was then anesthetized with ether. The abdomen of each anesthetized mouse was opened, and the pylorus was ligated; the abdomen was then closed after the sample solutions had been placed in the duodenal tract. Four hours after sealing-up their abdomens, the mice were anesthetized with ether, the stomachs were excised, and gastric juices were collected. These were centrifuged at $2,500 \times \mathrm{g}$, and then the gastric juice volumes and $\mathrm{pH}$ values were measured and total acid output was calculated. The total acid output was determined by titration versus $0.05 \mathrm{~N} \mathrm{NaOH}$ using phenolphthalein as an indicator [15].

\section{Statistical Analysis}

Results are expressed as means \pm SD $(n=9)$. Statistical analysis was performed with Duncan's multiple range tests. Differences were considered significant at $p<0.05$. 


\section{RESULTS}

Analgesic Effects of the MeOH Extract of A. tegmentosum Heartwood and its Fractions

The analgesic and anti-gastropathic effects of the $\mathrm{MeOH}$ extract of A. tegmentosum heartwood were evaluated in mice since $A$. tegmentosum has been used to prevent or treat alcohol poisoning in the folkloric medicinal society of Korea. Excessive drinking often causes headache, abdominal pain and gastric disorders. In addition, phytochemical isolation was also performed to identify the biologically active substance in the heartwood.

As shown in Table 1, the $\mathrm{MeOH}$ extract of A.tegmentosum heartwoods alleviated pain and had gastropathic action, indicative of why it has been used to treat alcohol poisoning. Among the $\mathrm{MeOH}$ extract and its $\mathrm{CHCl}_{3^{-}}, \mathrm{BuOH}-$ and $\mathrm{H}_{2} \mathrm{O}$ fractions, the $\mathrm{BuOH}$ fraction exhibited the most potent effect. Administration of 100 or $200 \mathrm{mg} / \mathrm{kg}$ of $\mathrm{BuOH}$ fraction significantly lengthened the jumping latency in the hot plate test from $10.3 \pm 3.17$ seconds for the control group to $15.2 \pm$ 2.41 seconds or $17.9 \pm 2.38$ seconds, respectively. Control mice had a writhing number of $66.4 \pm 2.41$ compared to 53.4 \pm 2.70 at the $100 \mathrm{mg} / \mathrm{kg}$ dose and $45.4 \pm 2.88$ at the 200 $\mathrm{mg} / \mathrm{kg}$ dose for the $\mathrm{BuOH}$ fraction-treated group. Thus, the A. teg mentosum extracts exhibited central and peripheral analgesic effects in the hot plate test and the writhing test.

Effects of the MeOH Extract of A.t egmentosum Heartwood and its Fractions on Gastropathy

Ulcerative indices were determined in mice with $\mathrm{HCl} / \mathrm{ethanol-}$ and indomethacin/bethanechol-induced ulcers by measuring ulcerative lesion diameter. As shown in Table 2, treatment with $0.3 \mathrm{M} \mathrm{HCl}$ and $60 \% \mathrm{EtOH}$ caused gastric ulcers (diameter $27.4 \pm 2.10 \mathrm{~mm}$ ); however, pretreatment with the $\mathrm{MeOH}$ extract (100 and $200 \mathrm{mg} / \mathrm{kg}$, p.o.) for 2 weeks reduced the ulcerative index compared to the control group. Indomethacin, a non-steroidal anti-inflammatory drug, and bethanechol, a cholinergic drug, were also admin- istered to mice to induce gastric ulcers. Treatment with indomethacin/bethanechol caused gastric ulcers (diameter 14.7 $\pm 0.93 \mathrm{~mm}$ ), whereas pretreatment with the $\mathrm{MeOH}$ extract reduced the ulcerative index compared to the control. Among the $\mathrm{CHCl}_{3^{-}}, \mathrm{BuOH}-$ and $\mathrm{H}_{2} \mathrm{O}$ fractions, the $\mathrm{BuOH}$ fraction had the most potent anti-gastropathic activity. $\mathrm{HCl} / \mathrm{EtOH}$ caused gastric ulcers (diameter $27.4 \pm 2.10 \mathrm{~mm}$ ), while treatment with the $\mathrm{BuOH}$ fraction decreased the diameter to $21.7 \pm 3.43 \mathrm{~mm}$ and $18.9 \pm 2.11 \mathrm{~mm}$ at 100 and $200 \mathrm{mg} / \mathrm{kg}$ doses, respectively. Furthermore, in the indomethacin/bethanechol-induced gastric ulcer, treatment with the $\mathrm{BuOH}$ fraction reduced the ulcerative index from $14.7 \pm 0.93$ $\mathrm{mm}$ in the control group to $10.8 \pm 0.39 \mathrm{~mm}$ and $9.4 \pm 0.50$ $\mathrm{mm}$ at the 100 and $200 \mathrm{mg} / \mathrm{kg}$ doses, respectively.

Effects of the MeOH Extract of A. tegmentosum Heartwood and its Fractions on Gastric Juice Secretion

The volume of gastric juice was measured using the method described by Dai and Ogle [15]. The $\mathrm{pH}$ values and total acid output were also measured. The effects of the $\mathrm{MeOH}$ extract and its fractions on gastric secretion in pylorus-ligated mice are shown in Table 3 . Oral administration of the $\mathrm{MeOH}$ extract resulted in an increase of $\mathrm{pH}$ and decreases of gastric juice volume and total acid output in the pylorus-ligated mice at the 100 and $200 \mathrm{mg} / \mathrm{kg}$ doses. The $\mathrm{BuOH}$ fraction exhibited the most potent effects among the $\mathrm{MeOH}$ extract and tested fractions, suggesting that the bioactive compound was contained in the $\mathrm{BuOH}$ fraction.

\section{Isolation and Analgesic Effects of Salidroside}

Phytochemical isolation of the $\mathrm{BuOH}$ fraction led to the isolation of compound $\mathbf{1}$, which was identified as salidroside by comparing its spectroscopic data with the literature [11] (Fig. 1). As shown in Fig. (2), salidroside exhibited significant analgesic and anti-gastropathic effects at 10 and 20 $\mathrm{mg} / \mathrm{kg}$ dosages (p.o.). Oral administration of morphine (positive control, $10 \mathrm{mg} / \mathrm{kg}$, p.o.) lengthened the reaction time in the hot plate test by $176 \%$, while 10 and $20 \mathrm{mg} / \mathrm{kg}$ dosages of salidroside prolonged the reaction time by $68.0 \%$ and

Table 1. Anti-Nociceptive Effect of the MeOH Extract of A. tegmentosum Heartwood and Its Fractions in Hot-Plate Test and Acetic Acid-Induced Writhing Syndrome in Mice

\begin{tabular}{|c|c|c|c|}
\hline Group & Dose (mg/kg) & Stretching Episode (count/min) & Action Time (sec) \\
\hline Control & - & $66.4 \pm 2.41^{\mathrm{a}}$ & $10.3 \pm 3.17^{\mathrm{g}}$ \\
\hline \multirow[t]{2}{*}{$\mathrm{MeOH}$ extract } & 100 & $63.4 \pm 2.70^{\mathrm{ab}}$ & $13.2 \pm 2.96^{\operatorname{defg}}$ \\
\hline & 200 & $56.6 \pm 2.70^{\mathrm{c}}$ & $14.2 \pm 1.33^{\text {cdefg }}$ \\
\hline $\mathrm{CHCl}_{3}$ fraction & 100 & $63.4 \pm 2.30^{\mathrm{ab}}$ & $11.9 \pm 2.16 \mathrm{f}^{g}$ \\
\hline $\mathrm{BuOH}$ fraction & 200 & $45.4 \pm 2.88^{\mathrm{e}}$ & $17.9 \pm 2.38^{\mathrm{bc}}$ \\
\hline \multirow[t]{2}{*}{$\mathrm{H}_{2} \mathrm{O}$ fraction } & 100 & $56.2 \pm 3.19^{\mathrm{cd}}$ & $14.6 \pm 2.18^{\text {cdef }}$ \\
\hline & 200 & $52.6 \pm 2.70^{\mathrm{d}}$ & $16.8 \pm 2.06^{\text {bcde }}$ \\
\hline Aspirin & 100 & $16.2 \pm 1.30^{\mathrm{h}}$ & - \\
\hline
\end{tabular}

Samples were administered orally for one week and mice were tested one hour after the last treatment. Data are mean \pm SD value ( $\mathrm{n}=9$ mice per group). Values followed by superscripted letters are significantly different $(p<0.05)$ by Duncan's multiple range test. 
Table 2. Effect of the MeOH Extract of A.t egmentosum Heartwood and Its Fractions on HCl-Ethanol- and IndomethacinBethanechol-Induced Gastric Ulcers in Mice

\begin{tabular}{|c|c|c|c|}
\hline Group & Dose & Ulcerative Index (mm) \\
\hline & $(\mathrm{mg} / \mathrm{kg})$ & $27.4 \pm 2.10^{\mathrm{a}}$ & Indomethacin-Bethanechol \\
\hline \hline Control & - & $26.2 \pm 3.12^{\mathrm{abc}}$ & $14.7 \pm 0.93^{\mathrm{a}}$ \\
\hline $\mathrm{MeOH}$ extract & 100 & $22.5 \pm 4.25^{\mathrm{bcd}}$ & $11.2 \pm 0.50^{\mathrm{e}}$ \\
\hline $\mathrm{CHCl}_{3}$ fraction & 200 & $28.9 \pm 3.46^{\mathrm{a}}$ & $14.1 \pm 0.72^{\mathrm{abc}}$ \\
\hline & 100 & $26.5 \pm 4.17^{\mathrm{ab}}$ & $13.2 \pm 0.61^{\mathrm{cd}}$ \\
\hline $\mathrm{BuOH}^{\mathrm{b}}$ fraction & 200 & $21.7 \pm 3.43^{\mathrm{cd}}$ & $10.8 \pm 0.39^{\mathrm{ef}}$ \\
\hline & 100 & $18.9 \pm 2.11^{\mathrm{d}}$ & $9.4 \pm 0.50^{\mathrm{g}}$ \\
\hline $\mathrm{H}_{2} \mathrm{O}$ fraction & 200 & $25.9 \pm 1.43^{\mathrm{d}}$ & $12.9 \pm 0.33^{\mathrm{d}}$ \\
\hline & 100 & $20.6 \pm 2.53^{\mathrm{d}}$ & $10.5 \pm 0.41^{\mathrm{ef}}$ \\
\hline Cimetidine & 200 & $2.36 \pm 1.86^{\mathrm{e}}$ & - \\
\hline
\end{tabular}

Samples were administered orally for two weeks before $\mathrm{HCl} /$ ethanol or indomethacin/bethanechol induction of gastric ulcers in mice. Data are mean $\pm \mathrm{SD}$ value $(\mathrm{n}=9$ mice per group). Values followed by superscripted letters are significantly different $(p<0.05)$ by Duncan's multiple range test.

Table 3. Effect of the MeOH Extract of A. teg mentosum Heartwood and Its Fractions on the Biochemical Parameters of Gastric Juice Obtained from Pylorus-Ligated Mice

\begin{tabular}{|c|c|c|c|c|}
\hline Group & Dose (mg/kg) & pH & Volume (mL) & Total Acid Output \\
\hline Control & - & $3.2 \pm 0.8^{\mathrm{b}}$ & $1.5 \pm 0.06^{\mathrm{b}}$ & $5.8 \pm 0.47^{\mathrm{a}}$ \\
\hline $\mathrm{MeOH}$ extract & 200 & $3.1 \pm 0.7^{\mathrm{b}}$ & $1.5 \pm 0.07^{\mathrm{b}}$ & $5.1 \pm 0.42^{\text {bcde }}$ \\
\hline $\mathrm{CHCl}_{3}$ fraction & 100 & $3.1 \pm 0.6^{\mathrm{b}}$ & $1.5 \pm 0.05^{\mathrm{b}}$ & $5.9 \pm 0.39^{\mathrm{a}}$ \\
\hline \multirow[t]{2}{*}{$\mathrm{BuOH}$ fraction } & 100 & $3.4 \pm 0.5^{\mathrm{ab}}$ & $1.4 \pm 0.05^{\mathrm{c}}$ & $5.0 \pm 0.45^{\text {cde }}$ \\
\hline & 200 & $3.6 \pm 0.4^{\mathrm{b}}$ & $1.3 \pm 0.07^{\mathrm{d}}$ & $4.6 \pm 0.37^{\mathrm{e}}$ \\
\hline \multirow[t]{2}{*}{$\mathrm{H}_{2} \mathrm{O}$ fraction } & 100 & $3.3 \pm 0.7^{\mathrm{b}}$ & $1.3 \pm 0.05^{\mathrm{d}}$ & $5.3 \pm 0.57^{\mathrm{abcd}}$ \\
\hline & 200 & $3.2 \pm 0.4^{\mathrm{b}}$ & $1.6 \pm 0.04^{\mathrm{a}}$ & $4.8 \pm 0.23^{\mathrm{de}}$ \\
\hline
\end{tabular}

Data are mean \pm SD value ( $n=9$ mice per group). Values followed by superscripted letters are significantly different $(p<0.05)$ by Duncan's multiple range test.

$100 \%$, which suggests that it exerts centrally mediated analgesic action. In the writhing test, $100 \mathrm{mg} / \mathrm{kg}$ aspirin, used as the positive control, decreased writhing number by $75.6 \%$, which is indicative of peripherally mediated analgesic action, while administration of 10 and $20 \mathrm{mg} / \mathrm{kg}$ salidroside inhibited the writhing number by $38.6 \%$ and $47.9 \%$, respectively. These results indicate that salidroside has both centrally and peripherally mediated analgesic activity.

\section{Effects of Salidroside on Gastropathy}

As shown in Fig. (3), cimetidine (100 mg/kg, p.o.), a positive control, inhibited the gastric lesion caused by $\mathrm{HCl} / \mathrm{EtOH}$ by $91.4 \%$, while administration of salidroside inhibited the gastric lesion diameter by $51.5 \%$ and $65.8 \%$ at the 10 and $20 \mathrm{mg} / \mathrm{kg}$ dosages, respectively. In the indo- methacin/bethanechol-induced gastric lesion, administration of 10 and $20 \mathrm{mg} / \mathrm{kg}$ of salidroside reduced the ulcerative index by $31.8 \%$ and $38.8 \%$, whereas omeprazol, a positive control, decreased the ulcerative index by $61.8 \%$. These results suggest that salidroside has anti-gastropathic activity. This compound also increased the $\mathrm{pH}$ of gastric juice and further decreased the volume of gastric juice and the total acid output, although its activities were weaker than those of cimetidine (Fig. 4).

\section{DISCUSSION AND CONCLUSION}

We sought to find the biologically active substance in $A$. tegmentosum heartwoods that has analgesic and antigastropathic actions in order to increase its pharmacological availability to relieve the symptoms of headache, abdominal 

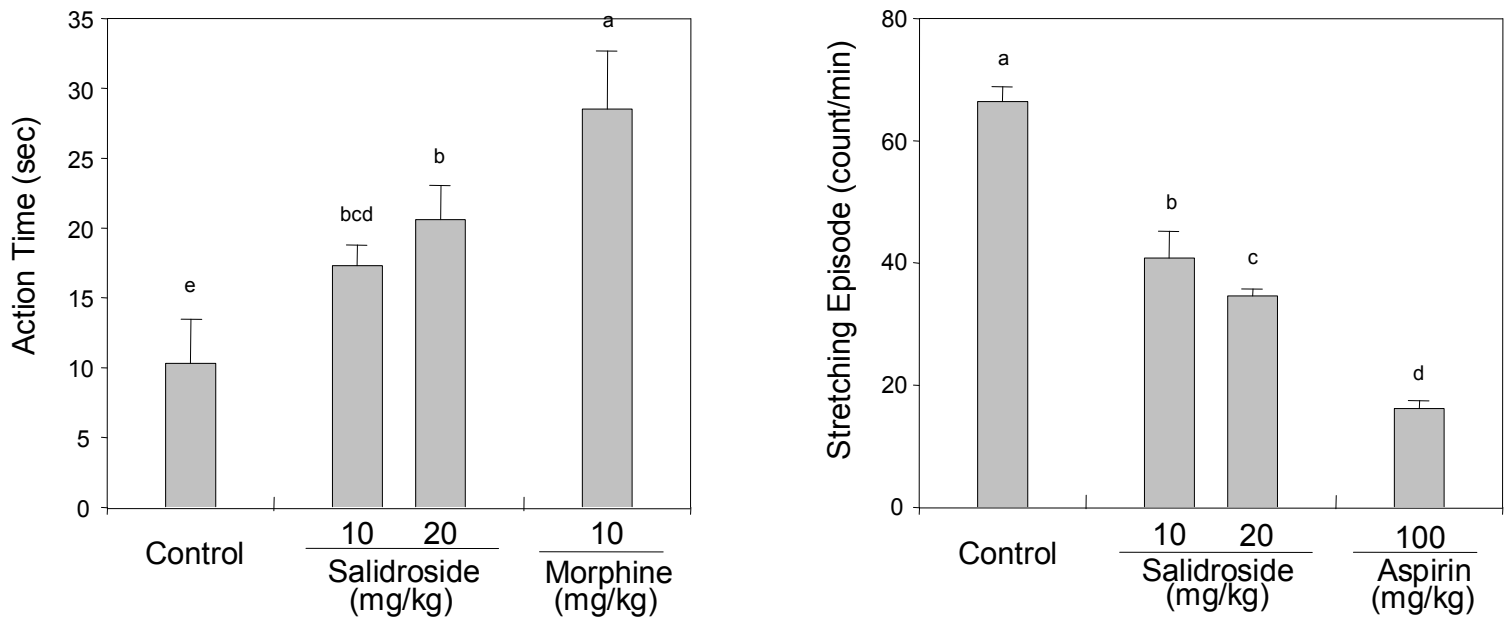

Fig. (2). Anti-nociceptive effect of salidroside from A. tegmentosum heartwood in hot-plate test (A) and acetic acid-induced writhing syndrome $(\mathbf{B})$ in mice. Values followed by superscripted letters are significantly different $(p<0.05)$ by Duncan's multiple range test.
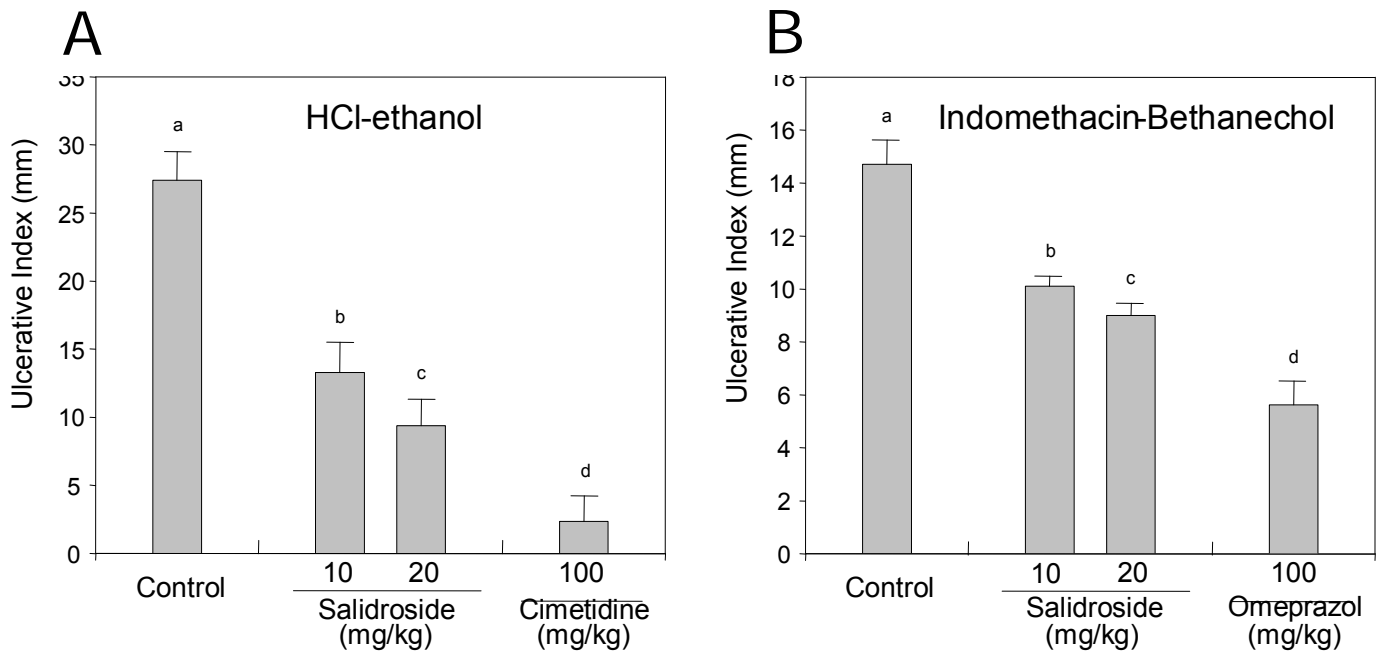

Fig. (3). Effect of salidroside from A. teg mentosum heartwood on $\mathrm{HCl} /$ ethanol- (A) and indomethacin/bethanechol- (B) induced gastric ulcers in mice. Values followed by superscripted letters are significantly different $(p<0.05)$ by Duncan's multiple range test.

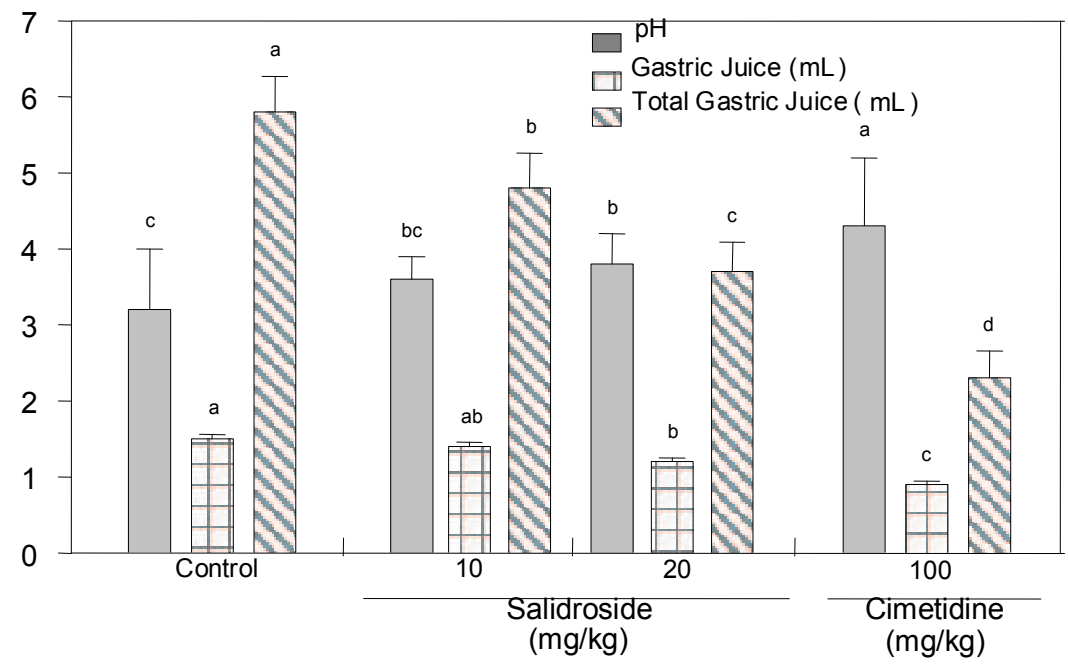

Fig. (4). Effect of salidroside from A. tegmentosum heartwood on the biochemical parameters of gastric juice obtained from pylorus-ligated mice. Compared among the bars with the same figure, values followed by the same superscripted letters are not significantly different $(p<$ $0.05)$ by Duncan's multiple range test.

pain and vomiting that can follow alcohol consumption. Based on our experimental results, A. tegmentosum heart- wood can be used as a therapeutic with analgesic and antigastropathic activity before or after drinking alcohol. 
Salidroside was the major biologically active substance in A. teg mentosum heartwood and it exhibited distinct analgesic activity and high anti-gastropathic activity at both the 10 and $20 \mathrm{mg} / \mathrm{kg}$ doses (p.o.). It also increased the $\mathrm{pH}$ of gastric juice and lowered the gastric juice volume, although its activities were weaker than those of cimetidine. Gastropathy is a disease that occurs frequently in modern society. There are many therapeutics to treat gastritis and digestive ulcers such as antacids, anticholinergic agents, $\mathrm{H}_{2}$ antagonists and $\mathrm{H}^{+}$-pump inhibitors and anti-Helicobacter $p$ ylori agents, although these medicinal drugs have unwanted side effects and the disease frequently returns [16-19].

There have been several reports of anti-ulcerative natural products such as flavonoids [20], sesquiterpene lactones [21], diterpenes [22] and saponins [23, 24]. In addition, the natural products with anti-Helicobacter pylori effects were reported to include alkaloids [25], sesquiterpenes [26], sesquiterpene lactones [27], flavonoids [28] and isoflavonoids [29]. Crude drugs with anti-ulcerative/anti-inflammatory activities [30] or with anti-ulcerative/anti-nociceptive activities [31] were also reported, suggesting that these medicinal herbal drugs have their effects via immunological or antioxidative mechanisms. Therefore, the anti-gastropathic activity of salidroside elucidated in the present study should be studied further to determine its mechanism of action. Based on the high anti-gastropathic activity of salidroside, it could be used to develop a therapeutic agent against gastric disease. For example, since 4-hydroxyphenylethyl alcohol, an aglycone of salidroside, has a simple structure and can be chemically synthesized, it could be developed as a new therapeutic agent using the chemical structure of salidroside.

\section{ACKNOWLEDGMENT}

This work was supported by a grant (Code \# 20050401034-695-183-01-00) from the BioGreen 21 Program, Rural Development Administration, Republic of Korea.

\section{REFERENCES}

[1] Pilotto, A. Aging and upper gastrointestinal disorders. Best Pract. Res. Clin. Gastroenterol., 2004, 18, 73-81.

[2] Aihara, T.; Nakamura, E.; Amagase, K.; Tomita, K.; Fujishita, T.; Furutani, K.; Okabe, S. Pharmacological control of gastric acid secretion for the treatment of acid-related peptic disease. Pharmacol. Ther., 2003, 98, 109-127.

[3] Behrman, S.W. Management of complicated peptic ulcer disease. Arch. Surg., 2005, 140, 201-208.

[4] Demir, S.; Yilmaz, M.; Koseoglu, M.; Akalin, N.; Aslan, D.; Aydin, A. Role of free radicals in peptic ulcer and gastritis. Turk. $J$. Gastroenterol., 2003, 14, 39-43.

[5] Perry, M.A.; Wadhwa, S.; Parks, D.A.; Pickard, W.; Granger, D.N. Role of oxygen radicals in ischemia-induced lesions in the cat stomach. Gastroenterology, 1986, 90, 362-267.

[6] Kim, T.J. Plant Resources in Korea. Publishing Co. Seoul. Seoul, 1996, Vol. III.

[7] Hur, J.M.; Jun, M.; Yang, E.J.; Choi, S.H.; Park, J.C.; Song, K.S. Isolation of isoprenoidal compounds from the stems of Acer tegmentosum max. Kor. J. Pharmacogn., 2007, 38, 67-70.

[8] Kubo, M.; Inoue, T.; Nagai, M. Studies on the constituents of Aceraceae plants. III. Structure of acerogenin B from Acer nikoense Maxim. Chem. Pharm. Bull., 1980, 28, 1300-1303.

[9] Kubo, M.; Nagai, M.; Inoue, T. Studies on the constituents of Aceraceae plants. Carbon-13 nuclear magnetic resonance spectra of acerogenin A, rhododendrol, and related compounds, and structure of aceroside from Acer nikoense. Chem. Pharm. B ull., 1983, 31, 1917-1922.
[10] Hatano, T.; Hattori, S.; Ikeda, Y.; Shingu, T.; Okuda, Y. Tannins of Aceraceous plants. Part II. Gallotannins having a 1,5-anhydro-Dglucitol core and some ellagitannins from Acer species. Chem. Pharm. Bull., 1990, 38, 1902-1905.

[11] Park, K.M.; Yang, M.C.; Lee, K.H.; Kim, K.R.; Choi, S.U.; Lee, K.R. Cytotoxic phenolic constituents of Acer tegmentosum maxim. Arch. Pharm. Res., 2006, 29, 1086-1090.

[12] Jung, H.J.; Choi, J.; Nam, J.H.; Park, H.J. Anti-ulcerogenic effects of effects of the flavonoid-rich fraction from the extract of Orostachys japonicus. J. Med. Food, 2007, 10, 702-706.

[13] Mizui, T.; Dodeuchi, M. Effect of polyamines on acidified ethanolinduced gastric lesions in rats. Jpn. J. Pharmacol., 1983, 33, 939945.

[14] Rainsford, K.D. A synergistic interaction between aspirin, or other non-steroidal anti-inflammatory drugs, and stress which produces severe gastric mucosal damage in rats and pigs. Agents Actions, 1975, 5, 553-558.

[15] Dai, S.; Ogle C.W. A simple method for the production of peptic ulceration in the rat. Life Sci., 1973, 12, 505-512.

[16] Sontag, S.; Graham, D.Y.; Belsito, A.; Weiss, J.; Farley, A.; Grund, R.; Cohen, N.; Koinnear, D.; Daois, W.; Archarmbault, A. Cimetidine, cigarette smoking and recurrence of duodenal ulcer. $N$. Engl. J. Med., 1994, 311, 689-693.

[17] Thomxon, A.B.; Mayai, S. Medical management of uncomplicated peptic ulcer disease Bochus Gastroenterology, Berk J.E.; EB Sanders Co. USA, 1985; pp. 1116-1119.

[18] Hentschel, E.; Brandstaffer, G.; Pragosics, B.; Hirschi, A.M.; Nemec, H.; Schutze, K.; Taufer, M.; Wurzer, H. Effect of radnitidine and amoxicillin plus metronidazole of the eradication of $\mathrm{H}$. pylori and the recurrence of duodenal ulcer. N. Eng. J. Med., 1993, 328, 308-312.

[19] Tames, D.L.; Warren, B.B.; Colleen, B.; John, T.F.; Brain, L.S. Hospitaligation and mortality rates from peptic ulcer disease and GI bleeding in the 1990s. Am. J. Gastrol., 2002, 97, 2540-2549.

[20] Lewis, D.A.; Fields, W.N.; Shaw, G.P. A natural flavonoid present in unripe plantain banana pulp (Musa sapientum var. paradisiacal) protects the gastric mucosa from aspirin-induced erosions. J. Ethnopharmacol., 1999, 65, 283-288.

[21] Yesilada, E.; Gurbuz, I.; Bedir, E.; Tatli, I.; Khan, I.A. Isolation of anti-ulcerogenic sesquiterpene lactones from Centaurea solstitialis L. ssp. Solstitialis through bioassay-guided fractionation procedures in rats. J. Ethnopharmacol., 2004, 95, 213-219.

[22] Melo, P.S.; Duran, N.D.; Hiruma-Lima, C.A.; Souza-Brito, A.R.M.; Haun, M. Comparison of the gastroprotective effect of a diterpene lactone isolated from Croton cajucara with its synthetic derivatives. J. Ethnopharmacol., 2003, 87, 169-174.

[23] Yesilda, E.; Takaishi, Y. A saponin with anti-ulcerogenic effect from the flowers of Spartium junceum. Phytochemistry, 1999, 51, 903-908.

[24] Yoshikawa, M.; Murakami, T.; Kishi, A.; Kageura, T.; Matsuda, H. Medicinal flowers. III. Marigold. (1): Hypoglycemic, gastric emptying inhibitory, and gastroprotective principles and new oleananetype triterpene oligoglycosides, Calendasaponins A, B, C, and D, from Egyptian Calendula officinalis. Chem. Pharm. Bull., 2001, 49, 863-870.

[25] Carroll, A.R.; Ngo, A.N.; Quinn, R.J.; Redburn, J.; Hooper, N.A Petrosamine $\mathrm{B}$, an inhibitor of the Helicobacter pylori enzyme aspartyl semialdehyde dehydrogenase from the Australian sponge Oceanapia sp. J. Nat. Prod., 2005, 68, 804-806.

[26] Ochi, T.; Shibata, H.; Higuti, T.; Kodama, K.; Kusumi, T.; Takaishi, Y. Anti-Helicobacter pylori compounds from Santalum album. J. Nat. Prod., 2005, 68, 819-824.

[27] Konstatinopoulou, M.; Karioti, A.; Skaltsas, S.; Skaltsa, H. Sesquiterpene lactones from Anthemis a ltissima and their antiHelicobacter pylori. J. Nat. Prod., 2003, 66, 699-702.

[28] Fukai, T.; Marumo, A.; Kanda, T.; Terada, S.; Nomura, T. AntiHelicobacter $p$ ylori flavonoids from licorice extract. $L$ ife $S \mathrm{ci}$., 2002, 71, 1449-1463.

[29] Takashima, J.; Chiba, N.; Yoneda, K.; Ohsaki, A. Derrisin, a new rotenoid from Derris malaccensis plain and anti-Helicobacter pylori activity of its related constituents. J. Nat. Prod., 2002, 65, 611613.

[30] Guardia, T.; Juarez, A.O.; Guarreiro, E.; Guzman, J.A.; Pelze, L. Antiinflammatory activity and effect on gastric acid secretion of 
dehydroleucodine isolated from Artemisia douglasiana. J. Ethnopharmacol., 2003, 88, 195-198.
[31] Gonzalez, F.G.; Stasi, L.C.D. Anti-ulcerogenic and analgesic activities of the leaves of Wilbrandia ebracteata in mice. Phytomedicine, 2002, 9, 125-134.

(C) Yoo et al.; Licensee Bentham Open.

This is an open access article licensed under the terms of the Creative Commons Attribution Non-Commercial License (http://creativecommons.org/licenses/by$\mathrm{nc} / 3.0 /$ ) which permits unrestricted, non-commercial use, distribution and reproduction in any medium, provided the work is properly cited. 